ISSN 2080-1653

DOI 10.24917/20801653.343.9

\author{
OLEKSANDR KOROL \\ Yuriy Fedkovych Chernivtsi National University, Ukraine \\ VOLODYMYR KRUL \\ Yuriy Fedkovych Chernivtsi National University, Ukraine
}

\title{
Classification of Countries of Destination by Gross and Relative Values of International (Inbound) Tourism and its Factors
}

\begin{abstract}
The present work is aimed at the analysis of gross and relative values of inbound tourism by countries of destination for the purpose of their classification. As a result of confronting total and specific (per $1 \mathrm{~km}$ of conventional radius of the country's territory) numbers of international tourist arrivals with the median values for 100 countries of the world as of 2016, countries of destination were divided into four classes. Small countries of intensive inbound tourism are predominantly represented by tropical islands of the Caribbean Basin and Indian Ocean, as well as by the Mediterranean region. Over half of big countries of intensive inbound tourism are located in Europe and the Mediterranean destinations were the most often visited ones. Big countries of extensive inbound tourism show significant volume of inbound tourism in the first place due to their significant territories. Among these, there were Scandinavian destinations of Europe, Canada and Russia. The low intensity of their inbound tourism is explained by the unfavourable climate for human thermal-physiological sensations. Small countries of not-intensive inbound tourism had considerably less volume and intensity of tourism arrivals due to their small territories, unfavourable geographical conditions, but, what is most essential, also due to the poverty. In addition, cost indicator, that is receipts from inbound tourism per one arrival, was taken into account in the analysis. The factors that have influence over it were also disclosed.
\end{abstract}

Keywords: classification of countries of destination; factors of inbound tourism; international tourist arrivals; profitability of inbound tourism; receipts from inbound tourism

Received: 9 October 2019

Accepted: 8 June 2020

\section{Suggested citation:}

Korol, O., Krul, V. (2020). Classification of Countries of Destination by Gross and Relative Values of International (inbound) Tourism and its Factors. Prace Komisji Geografii Przemyslu Polskiego Towarzystwa Geograficznego [Studies of the Industrial Geography Commission of the Polish Geographical Society]. 34(3), 130-149. doi: 10.24917/20801653.343.9

\section{INTRODUCTION}

Tourism in postindustrial society plays an important role in economics of many countries. Significance of international tourism in the world trade is still more essential since it forms an external imbalance in export/import transactions. 
Different countries of the world are differently involved in international tourism, for example, the European Region accounts for half of tourist arrivals. This is why it is interesting to know which countries receive bigger number of international tourists, and which fall behind. However, gross arrivals cannot show the intensity of inbound tourism which can only be measured if confronted with some other quantitative characteristics of the country of destination, and it is a matter of this research to ascertain exactly what they are. At length, gross and relative values of inbound tourism, inclusive of cost indicators, can be used to help classify tourists' countries of destination, while essential common features in countries of the same class may point to specific factors of international tourism.

\section{ANALYSIS OF THE LATEST STUDIES AND PUBLICATIONS}

Considering the geographical nature of tourism as a form of migration of the population which is connected with the peculiarities of the distant territories (water areas), that is, with the differences "from place to place", significant contribution in this sphere belongs particularly to the geographers, which is reflected in the writings of V. Preobrazhensky, Yu. Vedenin, I. Zorin, M. Ananiev, N. Zachinyayev, N. Falkovich, Ye. Kotlyarov, M. Krachylo. Among the recent important works devoted to international tourism, we would like to accentuate upon the writings of A. Aleksandrova (2002), 0. Liubitseva (2003) etc. The authors describe the main concepts of international tourism, analyse the geography of tourist demand in the regions of the world, reveal the latest trends and processes of globalisation in the tourism sphere. Among foreign works it is worth mentioning the publication of Boniface \& Cooper (2009), which is devoted to the geography of tourism, in particular the analysis of destinations by regions of the world. The latest statistical information can be found in the annual analytical electronic edition "UNWTO Tourism Highlights" (UNWTO, 2001-2017).

\section{STUDY GOALS}

The present work is aimed at the analysis of gross and relative values of inbound tourism by countries of destination for the purpose of their classification. Moreover, the authors aimed to disclose factors that predefine volume, intensity and profitability of inbound tourism.

\section{STUDY MATERIALS AND METHODICAL BASES}

The present study bases on statistics and methodology of international tourism evaluation suggested by the United Nations World Tourism Organization (UNWTO) and made use of by the World Bank. In particular, inbound tourism is assessed in physical and monetary indices such as international tourism arrivals and receipts from inbound tourism.

No matter which way you slice it, gross arrivals will not account for destination attractiveness, since big northern country often will be visited by bigger number of tourists than a small Mediterranean island. For example, in 2016 Finland was visited by 1.4 times more tourists than Malta. In other words, it seems reasonable 
to abstract our mind from the country's size and suggest a relative value to help account for tourism attractiveness irrespective of the country being big or small.

First of all, the size of the country is the number of its population or the area of its territory. Hence, the division of the number of arrivals by one of these values gives a relative index that would allow for the comparison of tourism attractiveness of different countries irrespective of the country's scale.

If the number of population of the destination country is to become a basis for calculations of relative value, one should remember that international tourists originate from the population of another country. That is, they have no direct concern with local people. It should also be remembered that severe climate is not favourable for both tourism and everyday living. Nonetheless, the proportion of small number of tourists $(1,792,000)$ who visited Iceland in 2016 and a miserable number of local people $(332,000)$ was 3.4 times bigger than that for Spain, and 4.5 times for France. In other words, an island amid northern waters of the Atlantics with its sub-arctic climate appeared to become more attractive than two most popular Mediterranean tourism destinations where, due to favourable climate conditions, much more people live. It is obvious that such calculations have nothing to do with reality.

Thus, it is the area of the country's territory that will allow us to unbind from demographic scale of the country. When calculating a relative value as physical criterion of inbound tourism attractiveness, it should be remembered that the number of international tourism arrivals is a linear value, while the area of the territory represents quadratic one. Hence, the larger the country, its area will change squared, while the arrivals would change linearly. It should also be emphasized that the bigger the territory of the country, less chances it will have to win leading positions in the top list. It is fair, since the latter appears from the number of arrivals per $1 \mathrm{~km}^{2}$, and, the bigger the area of the territory, the denominator will grow more intensively than the numerator, as was established in previous studies (Korol, 2018).

To reduce quadratic value to a linear, we should abstract our minds from specific forms of the country's surface. For this purpose, a real area of the country's territory can be represented as a circle with the radius calculated through the country's area:

$$
R=\sqrt{\frac{S}{\pi}}
$$

where: R - a conventional radius of the country's territory; - a real area of the country's territory.

Proceeding from the above, the physical criterion of inbound tourism attractiveness (Atr) is suggested to be defined as a number of international tourism arrivals $(A r r)$ per $1 \mathrm{~km}$ of the conventional radius of the country's territory $(R)$ :

$$
\text { Atr }=\frac{A r r}{R}
$$

Another index available with the UNWTO assessments of international tourism is, as was stated above, the receipts from inbound tourism. It is in its essence similar to gross arrivals except that it is not counted in the number of tourists but in the money 
they have spent. However, a relative cost index that shows the profitability of inbound tourism (Inc) seems in our case to be more informative. It is not a new index and is calculated as a relation of receipts from inbound tourism $(R e c)$ and the number of international tourism arrivals (Arr):

$$
\text { Inc }=\frac{\operatorname{Rec}}{A r r}
$$

The profitability of inbound tourism can depend on the distance to tourists' countries of origin and high prices in countries of destination expressed by per capita consumption expenditures of local population. The distance covered by tourists on their way to destination can be illustrated through the average distance from top countries of their origin, calculated as weighted mean by share of arrivals. And, since there can be many such countries in the structure of inbound tourism, it would be reasonable to limit ourselves to top-5 countries. With that, these five should account for no less than $50 \%$ of all arrivals, or the number of the countries should be extended so that they fit the minimally required percentage. To simplify calculations, we took the smallest distance between the state borders of countries of tourists' origin and destination. In particular, "zero" distance was appropriated to countries-neighbours who had common land border. Such an approach seems to be well-grounded, since the UNWTO international tourism assessment standards give preference to counting arrivals on the state border check points, that is, formally, a tourist flow is assessed from a state border to a state border. Hence, to measure weighted average distance covered by tourists on their way to destination, we suggested the formula as follows:

$$
D=\frac{D_{1} W_{1}+D_{2} W_{2} \ldots+D_{n} W_{n}}{W_{1}+W_{2} \ldots+D_{1} W_{1}+W_{n}}
$$

where: $\mathrm{D}$ - weighted average distance; $\mathrm{W}_{\mathrm{i}}$ - percentage of arrivals from the country of origin (i); $D_{i}$ - the least distance $(\mathrm{km})$ between state borders of countries of origin (i) and destination.

The profitability of inbound tourism also can depend on tourists' expenditures in destination, which may correlate with their well-being. This is why it is important to assess their potentials of spending power. We suggested per percentage of arrivals average weighted tourism expenditures per one departure for tourists' countries of origin:

$$
E_{x p}=\frac{E_{x p 1} W_{1}+E_{x p 2} W_{2} \ldots+E_{x p n} W_{n}}{W_{1}+W_{2} \ldots+W_{n}}
$$

where: Exp - tourism expenditures per departure of countries of origin weighted average per percentage of arrivals in the structure of inbound tourism of country of destination; $W_{i}$ - percentage of arrivals from countries of origin (i); $\operatorname{Exp}_{\mathrm{i}}$ - tourism expenditures per departure, calculated for countries of origin (i).

Since there can be many countries of tourists' origin in the structure of arrivals, is seems reasonable to limit ourselves to top 5 countries. Besides, for the purpose of better representation, the total share in the structure of arrivals was no less than $50 \%$. 


\section{STUDY RESULTS}

Classification of destinations was performed for 100 countries of the world on the basis of the excerption's median values of gross (Arr) and relative (Atr, Inc) indices of inbound tourism as of 2016. With that, gross and relative physical indices were compared first, and then the specific cost categories were outlined within the limits of that comparison. Median gross arrivals in this excerption which amounted to 3.468 million people in 2016 were chosen as "watershed" for physical indices, as well as the median arrivals per $1 \mathrm{~km}$ of the conventional radius of the country's territory which made 20.09 thousand. These median parametric indices have divided the whole data massif into four fields (see Figure 1). In each of these, countries of destination were also subdivided into two categories: those with more or less than median tourism receipts per arrival, which were $\$ 923.00$ in 2016.

Field I is represented by countries with gross arrivals smaller than the median value for this excerption ( 3.468 million) and physical criterion of inbound tourism attractiveness (Atr) exceeding 20.09 thousand. Such countries can be classified as small countries of intensive inbound tourism (see Table 1).

This is a class of insular destinations (except for Costa Rica, Estonia, Slovenia, Luxemburg and Israel) covering tropical islands of the Caribbean Basin, Indian Ocean, and Mediterranean region and making 2/3 out of all countries belonging to this field. High inbound tourism attractiveness of these destinations has become possible due to climatic conditions favourable for swimming and beach recreation, that is, tropical (Aw) and Mediterranean (Csa) types of climate in combination with sea water areas. These countries were not covered by Field II (countries with big number of arrivals) due to smallness of their territories.

Furthermore, this field includes European countries that do not belong to sea destinations, such as Estonia and Luxemburg. These are also characterised by small territory, but their higher inbound tourism attractiveness was favoured by their disposition in the united Europe, and the factor of neighbourhood. The Luxemburg's four major tourist markets are its neighbouring countries and the Netherlands, which totally accounted

Figure 1. Classification of countries of destination

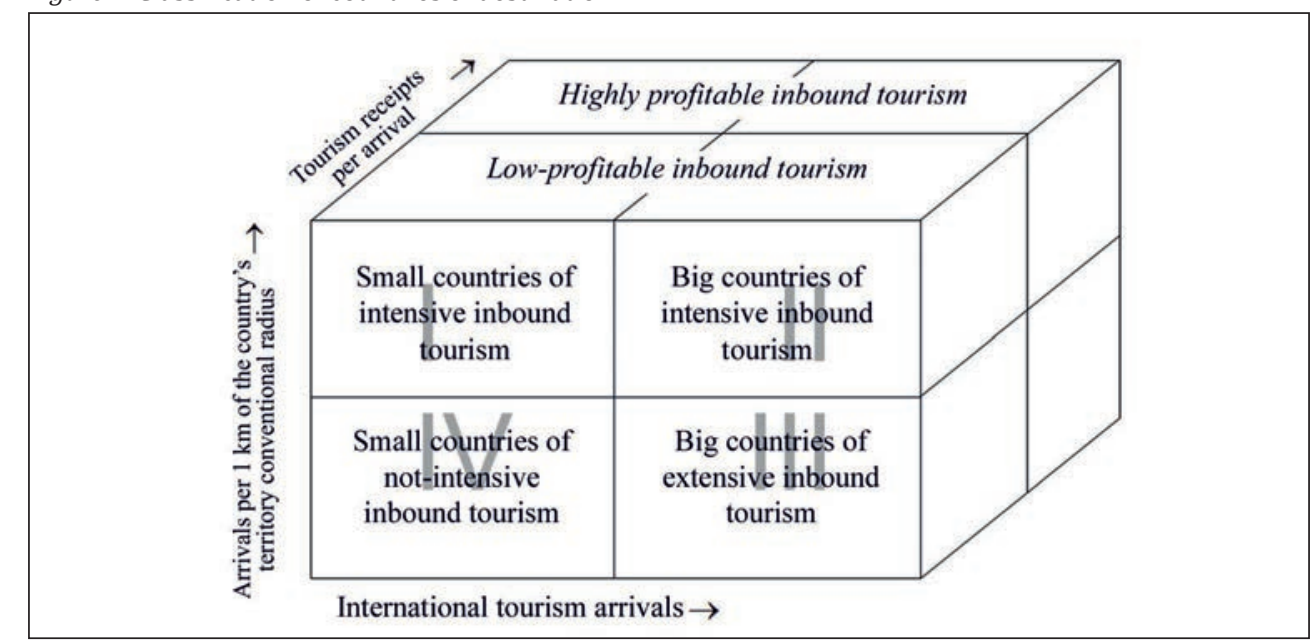

Source: authors' own work 
for over $62 \%$ of overnight stays in 2016 made up of the Netherlands (25.6\%), Belgium (17.3\%), Germany (11.2\%) and France (8.3\%). The same share of inbound tourists $(63 \%)$ in the Estonian accommodation establishments was attributable to neighbouring countries with tourists coming from Finland, Russia and Latvia (OECD, 2018).

Table 1. Small countries of intensive inbound tourism (2016)

\begin{tabular}{|c|c|c|c|c|}
\hline № & Country & Arrivals & $\begin{array}{c}\text { Arrivals per } \\
\text { territory radius }\end{array}$ & $\begin{array}{l}\text { Receipts (US\$) per } \\
\text { arrival }\end{array}$ \\
\hline 1 & Costa Rica & $2,925,000$ & 22,935 & 1,291 \\
\hline 2 & Israel & $2,900,000$ & 31,340 & 2,271 \\
\hline 3 & Jamaica & $2,182,000$ & 36,892 & 1,164 \\
\hline 4 & Bahamas & $1,499,000$ & 22,503 & 1,740 \\
\hline 5 & Maldives & $1,286,000$ & 131,600 & 2,053 \\
\hline 6 & Mauritius & $1,275,000$ & 50,035 & 1,431 \\
\hline 7 & Luxembourg & $1,054,000$ & 36,708 & 4,520 \\
\hline 8 & Barbados & 632,000 & 54,020 & 1,646 \\
\hline 9 & St. Lucia & 348,000 & 24,772 & 2,230 \\
\hline 10 & Seychelles & 303,000 & 25,040 & 1,667 \\
\hline 11 & Antigua and Barbuda & 265,000 & 22,392 & 3,034 \\
\hline \multicolumn{4}{|c|}{ median tourism receipts per arrival } & 923 US\$ \\
\hline 12 & Cyprus & $3,187,000$ & 58,734 & 865 \\
\hline 13 & Estonia & $3,131,000$ & 26,094 & 620 \\
\hline 14 & Slovenia & $3,032,000$ & 37,765 & 866 \\
\hline 15 & Malta & $1,966,000$ & 194,797 & 738 \\
\hline
\end{tabular}

Source: authors' own work based on World Bank Open Data

In accordance with the median for this excerption tourism receipts per arrival, the countries of Field I were divided into two categories: small countries of intensive low-profitable and highly profitable inbound tourism (see Table 1). The countries of highly profitable tourism include tropical insular countries, Costa Rica, Israel and Luxemburg. Except for the latter, high profitability in these countries is conditioned by the remoteness of these destinations from the regions of tourists' origin. In particular, because of insular disposition, these countries have no tourism flows from neighbours, which (flows) are as a rule of little profit due to frequency of visits and their short duration, and low tourism receipts should therefore be divided by a significant number of arrivals. Costa Rica and Israel are also visited by tourists from afar. The largest source market for overnight visitors of Costa Rica in 2016 was the United States (42.2\%), followed by Central America (24.8\%), Europe (14.9\%), and Canada (6.4\%). Therefore, the average length of stay in Costa Rica is between 11 and 13 nights (OECD, 2018). Tourists visiting remote destinations usually prefer to stay for a longer period and thus spend more money, in particular, for accommodation.

High profitability of inbound tourism in Luxemburg can be explained by high prices and wealthy visitors. Both are well illustrated by per capita household consumption expenditures. By these showing, Luxemburg was $4^{\text {th }}$ in the world in 2016, and the 
countries from where tourists were visiting Luxemburg stayed in pace, too. By the way, it is due to this precise reason that Estonia had the lowest for this field profitability (see Table 2). Even rich Finnish tourists who share $40 \%$ in the structure of total arrivals to Estonia do not spend much here. In other words, rich tourists, if they see the chance to cut down expenses in the destination, they will do that.

Table 2. Household consumption expenditure, per capita (2016)

\begin{tabular}{|c|l|c|}
\hline No & \multicolumn{1}{|c|}{ Country } & Prices as of 2010, US\$ \\
\hline \multicolumn{2}{|c|}{ Luksemburg } & 33,874 \\
\hline 1 & Netherlands & 22,388 \\
\hline 2 & Belgium & 23,230 \\
\hline 3 & Germany & 25,096 \\
\hline 4 & France & 23,379 \\
\hline
\end{tabular}

\begin{tabular}{|c|l|r|}
\hline No & Country & Prices as of 2010, US\$ \\
\hline \multicolumn{2}{|c|}{ Estonia } & 9,772 \\
\hline 1 & Finland & 25,734 \\
\hline 2 & Russia & 5,624 \\
\hline 3 & Latvia & 9,257 \\
\hline
\end{tabular}

Source: World Bank Open Data

Field II represents countries with gross arrivals that exceed 3.468 million and physical criterion of inbound tourism attractiveness (Atr) with over 20.09 thousand (see Table 3).

Table 3. Big countries of intensive inbound tourism (2016)

\begin{tabular}{|c|c|c|c|c|}
\hline № & Country & Arrivals & $\begin{array}{l}\text { Arrivals per territory } \\
\text { radius }\end{array}$ & $\begin{array}{l}\text { Receipts (US\$) per } \\
\text { arrival }\end{array}$ \\
\hline 1 & United States & $76,407,000$ & 44,236 & 3,222 \\
\hline 2 & United Kingdom & $35,814,000$ & 128,482 & 1,728 \\
\hline 3 & Germany & $35,555,000$ & 105,470 & 1,467 \\
\hline 4 & Thailand & $32,530,000$ & 80,422 & 1,613 \\
\hline 5 & Hong Kong, China & $26,553,000$ & $1,419,031$ & 1,418 \\
\hline 6 & Japan & $24,040,000$ & 69,319 & 1,391 \\
\hline 7 & Korea, Rep. & $17,242,000$ & 96,777 & 1,228 \\
\hline 8 & Netherlands & $15,828,000$ & 137,664 & 1,157 \\
\hline 9 & Portugal & $13,359,000$ & 77,900 & 1,286 \\
\hline 10 & Singapore & $12,914,000$ & 871,387 & 1,467 \\
\hline 11 & Ireland & $10,100,000$ & 67,532 & 1,131 \\
\hline 12 & Switzerland & $9,205,000$ & 80,293 & 2,088 \\
\hline 13 & Belgium & $7,481,000$ & 73,495 & 1,697 \\
\hline 14 & Dominican Republic & $5,959,300$ & 47,849 & 1,128 \\
\hline 15 & Hungary & $5,302,000$ & 30,811 & 1,411 \\
\hline 16 & Jordan & $3,567,000$ & 20,810 & 1,386 \\
\hline \multicolumn{4}{|c|}{ median tourism receipts per arrival } & 923 US\$ \\
\hline 17 & France & $82,682,000$ & 198,144 & 762 \\
\hline 18 & Spain & $75,315,000$ & 187,891 & 805 \\
\hline 19 & China & $59,270,000$ & 33,911 & 750 \\
\hline
\end{tabular}




\begin{tabular}{|c|c|c|c|c|}
\hline 20 & Italy & $52,372,000$ & 169,132 & 771 \\
\hline 21 & Mexico & $35,079,000$ & 44,270 & 588 \\
\hline 22 & Turkey & $30,289,000$ & 60,765 & 884 \\
\hline 23 & Austria & $28,121,000$ & 172,108 & 746 \\
\hline 24 & Malaysia & $26,757,000$ & 82,587 & 676 \\
\hline 25 & Greece & $24,799,000$ & 121,010 & 667 \\
\hline 26 & Poland & $17,471,000$ & 55,378 & 690 \\
\hline 27 & Croatia & $13,809,000$ & 102,934 & 711 \\
\hline 28 & Ukraine & $13,333,000$ & 30,415 & 129 \\
\hline 29 & Belarus & $10,935,400$ & 42,540 & 93 \\
\hline 30 & Denmark & $10,781,000$ & 92,055 & 654 \\
\hline 31 & Morocco & $10,332,000$ & 27,405 & 767 \\
\hline 32 & Romania & $10,223,000$ & 37,181 & 212 \\
\hline 33 & Bahrain & $10,158,000$ & 680,509 & 396 \\
\hline 34 & Czech Republic & $9,321,000$ & 58,828 & 755 \\
\hline 35 & Bulgaria & $8,252,000$ & 43,919 & 505 \\
\hline 36 & Tunisia & $5,724,000$ & 25,082 & 298 \\
\hline 37 & Cambodia & $5,012,000$ & 20,878 & 703 \\
\hline 38 & Albania & $4,070,000$ & 42,545 & 447 \\
\hline
\end{tabular}

Source: authors' own work based on World Bank Open Data

These countries can be classified as big countries of intensive inbound tourism. Over half of them belong to the European Tourism region, and predominantly to the European Union. On the whole, citizens of the united Europe are distinctive for their high tourism activity (50\% of the worldwide international tourism arrivals accounted for this region in 2016). Situation is favoured by the fact that the European Union concentrates many countries "without state borders" on a relatively small area that possesses diverse nature, rich historic-cultural heritage and developed tourism infrastructure. Population of these countries is rather wealthy to afford trips abroad. However, Field II contains no countries of the Scandinavian Peninsula (Sweden, Norway and Finland), as well as there is no Scandinavian state within the category of small countries of intensive inbound tourism.

Instead, such big Mediterranean destinations as France, Spain and Italy have become the most visited countries within both Field II and in the whole world (see Figure 1, Table 3). This was favoured by the Mediterranean (Csa) type of climate characterised by comfortable weather providing pleasure on the seaside in summer. Despite showing much less gross and relative physical values of inbound tourism, other Mediterranean destinations, such as Turkey, Greece and Croatia, were also included in Field II (see Table 3). Thus, a Mediterranean type of climate that is favourable for swimming and beach recreation in combination with sea water areas was a major factor of international tourists' increased interest towards these countries (also known as "European wine belt destinations"). 
The rest of European countries covered by Field II belong to the so-called "European beer belt". These are either located northwards from the $+10{ }^{\circ} \mathrm{C}$ annual isotherm, or have an intra-continental disposition, that is, no appropriate conditions for swimming and beach recreation. Nevertheless, summers in Great Britain, Germany, the Netherlands, Ireland, Switzerland, Belgium, Hungary, Austria, Poland, Denmark, Czech Rep. show temperatures that are comfortable and efficient for human thermal-physiological sensations. This provides for favourable background for other kinds of tourism. A question arises, if it is only Switzerland and Austria who have the Alps that so much attract international tourists, and if we take the European Union off the table, what else in these geographical conditions gives that huge number of arrivals to these countries? Most probably, the answer is that it is a highly developed settlement and tourism infrastructures formed on the background of high density of consumption expenditures of local population per $1 \mathrm{~km}^{2}$ of the territory (DCE).

Generally, the value of consumption expenditures defines the development of the tertiary sector of economy, since it is there where households spend much money to buy goods and services that the investments tend to grow, in the first place, in final consumer-associated spheres of business, in particular, in trade, services, etc, and tourism is one of the major components of the latter. This is why consumption expenditures by residents of a certain country are at the same time a factor and a source of development of tourism infrastructure that can be made use of for the purposes of not only domestic but also international tourism.

Hence, DCE has influence on the formation of international (inbound) tourism flows to this or that country through the development of tourism infrastructure. This was an issue of a separate study where the density of local population's consumption expenditures was correlated with specific (per $\mathrm{km}^{2}$ ) capital investments in tourism industry for 88 countries of the world. The study resulted in the establishment of closest relation between these two characteristics, in particular, when the density of consumption expenditures by local population was less than US $\$ 1.7$ million $/ \mathrm{km}^{2}$ (prices as of 1996), correlation coefficient amounted to $r=0.91$; when the same was over - specific capital investments in tourism stopped to increase and varied within US\$50 thousand/ $\mathrm{km}^{2}$ (prices as of 1996) (Korol, 2018). Such countries have their already formed and developed tourism infrastructure that attracts international tourists even without "sea, sun, and sand".

Table 4. Density of consumption expenditures of local population (DCE) in some large countries of intensive inbound tourism, average as of 1999, 2004 and 2008

\begin{tabular}{|l|c|}
\hline \multicolumn{1}{|c|}{ Country } & DCE, million US\$ $/ \mathrm{km}^{2}$ (prices as of 1996) \\
\hline Hong Kong, China & 82.004 \\
\hline Singapore & 60.338 \\
\hline Netherlands & 5.908 \\
\hline Japan & 5.809 \\
\hline Belgium & 4.845 \\
\hline Great Britain & 4.575 \\
\hline Switzerland & 4.385 \\
\hline Germany & 3.765 \\
\hline
\end{tabular}




\begin{tabular}{|l|l|}
\hline Korea, Rep. & 3.024 \\
\hline Italy & 2.778 \\
\hline France & 1.764 \\
\hline Austria & 1.582 \\
\hline
\end{tabular}

Source: authors' own work based on World Bank Open Data

Depending on median for this excerption tourism receipts per arrival ( $\$ 923.00)$, the countries covered by Field II can be divided into two categories: big countries of intensive low-profitable and highly profitable inbound tourism (see Table 3). The same as it was with Field I countries, as was stated above, profitability of inbound tourism can depend on the distance to tourists' countries of origin and high prices in countries of destination expressed by per capita consumption expenditures of local population. The controntation of the latter and the tourism receipts per arrival revealed almost close relation between them, since correlation coefficient was $r=0.67$ (see Figure 2).

The European Union's newcomers such as Poland, Croatia, Czech Rep., Romania, and Bulgaria were included into the category of big countries of intensive low-profitable inbound tourism. This was due to insufficient, if compared to the EU old members, specific consumption expenditures of local population that only sometimes exceeded per capita US\$10,000. The presence of Greece and Spain in this set can be at a stretch explained by the same cause, since they have only a little passed outside the limits of the confidence interval of 0.95 (see Figure 2). Instead, the presence of Italy, France, Austria and Denmark takes some explaining.

Figure 2. Dependence of profitability of inbound tourism on per capita consumption expenditures of local population within Field II countries (2016)

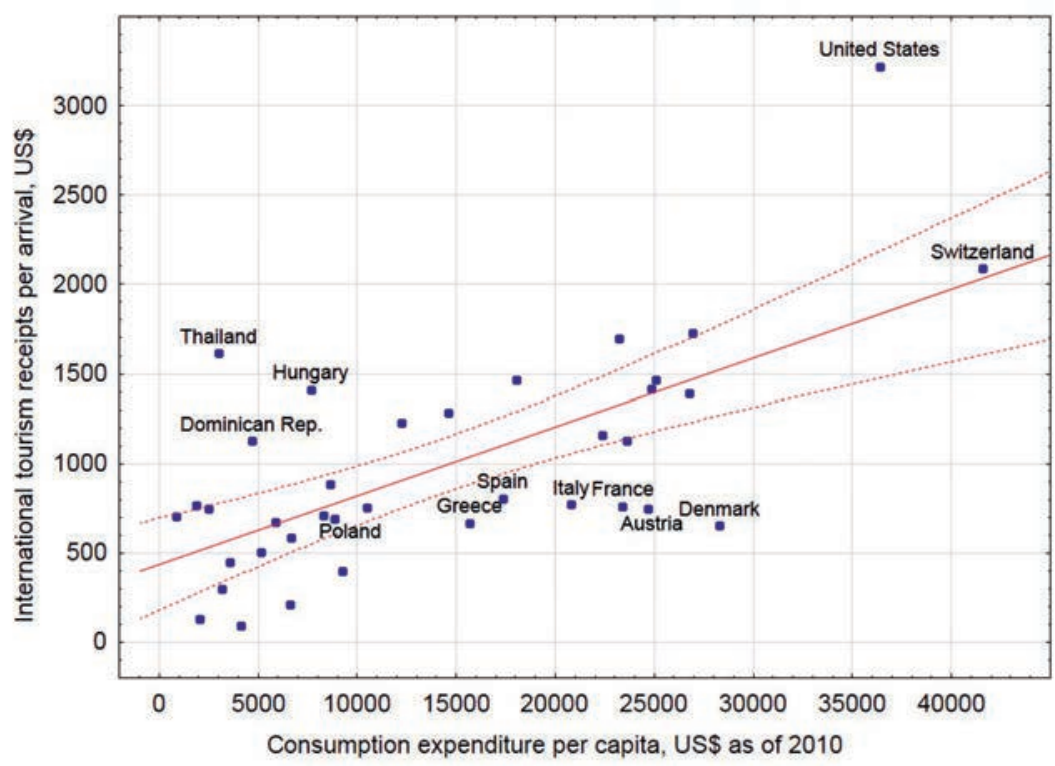

Source: authors' own work based on World Bank Open Data 
As was stated above, the profitability of inbound tourism depends on the distance to countries of tourists' origin. Essential receipts per arrival is usually observed in the countries that do not have long land state borders, or are even washed around from all sides by sea waters. Such geographical conditions prevent the unorganised tourism flows from the neighbours, that is, the structure of arrivals does not already contain mass frequent cheap trips that lower total profitability. And, if the country is at the same time distant from major tourism markets, this will essentially raise the price of transport component of the travel. Taking into account that tourism expenditures should always keep a balance between transport expenses and those in the destination, tourists as a rule stay in remote destinations for a longer time and spend more money.

A weighted average distance to countries of tourists' origin (see Formula 4) was calculated for Field II destinations whose figures on the diagram of distribution by per capita consumption expenditures and profitability of inbound tourism passed far beyond the limits of confidence interval of 0.95 (see Figure 2). As it was expected, France, Italy and Austria were mainly visited from the near, and it was only in Denmark and at the expense of tourists from the US that said distance was clearly bigger (see Table 5).

As stated earlier, the profitability of inbound tourism does not depend on only the distance covered by tourists but also on the per capita consumption expenditures of local population. Unfortunately, the number of cases with both values is too small to conclude on their common effect, while the complexity of weighted average distances (D) calculations require a special study. This was why we have made use of the previous study where a multiple regression analysis for 31 world countries was conducted in 2008 (Korol, 2018). The results of that study disclosed a tight dependence of profitability of inbound tourism on the weighted average distances to top-countries of tourists' origin and per capita household consumption expenditures of local population, since the coefficient of cumulative correlation was $\mathrm{R}=0.80$.

Table. 5. Structure of tourist arrivals, distances between the borders, and weighted average distance (2016)

\begin{tabular}{|c|l|r|c|}
\hline № & Country & $\begin{array}{c}\text { Arrivals, } \\
\%\end{array}$ & $\begin{array}{c}\text { Distances, } \\
\mathrm{km}\end{array}$ \\
\hline \multicolumn{4}{|c|}{ France } \\
\hline 1 & Germany & 13.8 & 0 \\
\hline 2 & Belgium & 11.5 & 0 \\
\hline 3 & Italy & 8.1 & 0 \\
\hline 4 & Switzerland & 7.3 & 0 \\
\hline 5 & Great Britain & 14.4 & 35 \\
\hline \multicolumn{3}{|c|}{ Weighted average distance } \\
\hline
\end{tabular}

\begin{tabular}{|c|c|c|c|}
\hline № & Country & $\begin{array}{c}\text { Arrivals, } \\
\%\end{array}$ & $\begin{array}{c}\text { Distances, } \\
\mathrm{km}\end{array}$ \\
\hline \multicolumn{4}{|c|}{ Italy } \\
\hline 1 & France & 12.2 & 0 \\
\hline 2 & Switzerland & 6.4 & 0 \\
\hline 3 & Austria & 6.7 & 0 \\
\hline 4 & Germany & 21.3 & 55 \\
\hline 5 & Great Britain & 8.3 & 730 \\
\hline \multicolumn{3}{|c|}{ Weighted average distances } & 132 \\
\hline
\end{tabular}

\begin{tabular}{|c|l|r|c|}
\hline \multicolumn{4}{|c|}{ Austria } \\
\hline 1 & Germany & 46.2 & 0 \\
\hline 2 & Italy & 3.9 & 0 \\
\hline 3 & $\begin{array}{l}\text { Switzerland and } \\
\text { Liechtenstein }\end{array}$ & 5.1 & 0 \\
\hline 4 & Netherlands & 6.6 & 450 \\
\hline 5 & Great Britain & 3.3 & 730 \\
\hline \multicolumn{3}{|l|}{ Weighted average distances } & 83 \\
\hline
\end{tabular}

\begin{tabular}{|c|l|r|c|}
\hline \multicolumn{4}{|c|}{ Denmark } \\
\hline 1 & Germany & 28.3 & 0 \\
\hline 2 & Sweden & 13.3 & 15 \\
\hline 3 & Norway & 16.4 & 115 \\
\hline 4 & Great Britain & 7.6 & 550 \\
\hline 5 & USA & 4.8 & 5,000 \\
\hline \multicolumn{3}{|l|}{ Weighted average distances } & 430 \\
\hline
\end{tabular}

Source: authors' own work based on OECD Tourism Trends and Policies and World Bank Open Data 
Four countries from the Big Seven, namely the USA, Japan, Great Britain, and Germany were appropriated to category of big countries of intensive highly profitable inbound tourism. The two latter, together with Ireland, the Netherlands, Belgium, and Switzerland comprise the so-called European beer belt. All of them are characterised by high level of per capita household consumption expenditures of over $\$ 20,000$. And it is due to high prices that these countries had tourism receipts per arrival that exceeded the median for the excerption value.

Another factor that explained high profitability of inbound tourism within the category of big countries was remote distance from the regions of tourists' origin. For example, Thailand, USA and Dominican Republic, that is, destinations whose figures on the diagram of distribution by per capita consumption expenditures and profitability of inbound tourism passed far beyond the limits of confidence interval of 0.95 (see Figure 2) showed a rather high weighted average distance to top countries of tourists' origin (see Table 6). The case of Hungary was not taken into account, since some doubts as the total arrivals appeared in the process of search for the information concerning the structure of international tourism, and this case therefore was considered unreliable.

Table 6. Structure of tourist arrivals, distances between the borders, and weighted average distance (2016)

\begin{tabular}{|c|c|c|c|}
\hline № & Country & $\begin{array}{c}\text { Arrivals, } \\
\%\end{array}$ & $\begin{array}{c}\text { Distances, } \\
\mathrm{km}\end{array}$ \\
\hline \multicolumn{4}{|c|}{ USA } \\
\hline 1 & Canada & 25.4 & 0 \\
\hline 2 & Mexico & 25.0 & 0 \\
\hline 3 & Great Britain & 6.0 & 4,130 \\
\hline 4 & Japan & 4.7 & 6,600 \\
\hline 5 & China & 3.9 & 7,000 \\
\hline \multicolumn{3}{|c|}{ Weighted average distance } & 1,279 \\
\hline
\end{tabular}

\begin{tabular}{|c|l|c|c|}
\hline № & \multicolumn{1}{|c|}{ Country } & $\begin{array}{c}\text { Arrivals, } \\
\%\end{array}$ & $\begin{array}{c}\text { Distances, } \\
\mathrm{km}\end{array}$ \\
\hline \multicolumn{3}{|c|}{ Dominican Republic } \\
\hline 1 & USA & 40.3 & 1,100 \\
\hline 2 & Canada & 14.8 & 2,700 \\
\hline 3 & France & 4.5 & 6,500 \\
\hline 4 & Great Britain & 3.2 & 6,500 \\
\hline 5 & Germany & 5.0 & 7,350 \\
\hline \multicolumn{3}{|c|}{ Weighted average distances } & 2,523 \\
\hline
\end{tabular}

\begin{tabular}{|r|l|r|r|}
\hline \multicolumn{3}{|c|}{ Thailand } \\
\hline 1 & Malaysia & 10.8 & 0 \\
\hline 2 & Laos & 4.3 & 0 \\
\hline 3 & China & 27.1 & 150 \\
\hline 5 & Singapore & 3.6 & 550 \\
\hline 6 & Korea & 4.5 & 2,900 \\
\hline 7 & Japan & 4.4 & 3,000 \\
\hline \multicolumn{3}{|c|}{ Weighted average distances } & 3,700 \\
\hline
\end{tabular}

Source: authors' own work based on OECD Tourism Trends and Policies and World Bank Open Data

Moreover, due to very intensive inbound tourism flows, such territorially small destinations as Hong Kong and Singapore were also included in the category of big countries. It should be emphasized that these two have become unquestioning leaders with respect to the number of tourist arrivals per $1 \mathrm{~km}$ of the territory's radius winning against the rest of the world by a landslide (see Table 3). As was already state above (see Table 4), this was due their high DCE value which showed by at least an order higher figures than those in the other developed countries. 
Field III is represented by countries manifesting the values of gross arrivals that exceed the median value for the excerption (3.468 million), and the values of physical criterion of inbound tourism attractiveness (Atr) that are less than 20.09 thousand. These can be classified as big countries of extensive inbound tourism. Among them there are Scandinavian destinations of Europe, Canada, Russia, Australia, the countries of South America, etc (see Table 7).

Low intensity of inbound tourist arrivals to Norway and Sweden is conditioned by their peninsular disposition and the Dfc type of climate characterised by the dominance of uncomfortable temperatures for human thermal-physiological sensations. These territories are also distinctive for still cooler tundra climate (ET).

Table 7. Big countries of extensive inbound tourism (2016)

\begin{tabular}{|r|l|c|c|c|}
\hline № & \multicolumn{1}{|c|}{ Country } & Arrivals & $\begin{array}{c}\text { Arrivals per territory } \\
\text { radius }\end{array}$ & $\begin{array}{c}\text { Receipts (US\$) } \\
\text { per arrival }\end{array}$ \\
\hline 1 & India & $1,4570,000$ & 14,243 & 1,586 \\
\hline 2 & Indonesia & $1,1519,000$ & 14,737 & 1,091 \\
\hline 3 & Australia & $8,269,000$ & 5,286 & 4,449 \\
\hline 4 & Sweden & $6,782,000$ & 17,920 & 1,882 \\
\hline 5 & Brazil & $6,547,000$ & 3,969 & 1,010 \\
\hline 6 & Philippines & $5,967,000$ & 19,369 & 1,054 \\
\hline 7 & Norway & $5,960,000$ & 17,003 & 1,055 \\
\hline 8 & Peru & $3,744,000$ & 5,854 & 923 US\$ \\
\hline & & $24,571,000$ & 10,539 & 522 \\
\hline 9 & Russia & $19,971,000$ & 11,202 & 906 \\
\hline 10 & Canada & $10,044,000$ & 16,118 & 877 \\
\hline 11 & South Africa & $6,655,000$ & 7,099 & 779 \\
\hline 12 & Argentina & $5,641,000$ & 11,492 & 660 \\
\hline 13 & Chile & $5,258,000$ & 9,313 & 629 \\
\hline 14 & Egypt & $3,853,000$ & 15,328 & 124 \\
\hline 15 & Kyrgyz Rep. & & \\
\hline
\end{tabular}

Source: authors' own work based on World Bank Open Data

The majority of the territories of Canada and Russia are distinctive for moderately cold climate (Dfb) not favourable for swimming and beach recreation, with admixtures of types of climate characteristic for Scandinavian Peninsula. However, due to huge territories, both countries have a long land state border, and this was the real cause for the provision of rather big number of international tourist arrivals (see Table 7). To prove the fact, over $70 \%$ of arrivals to Canada and Russia account for those from neighbouring countries.

On the opposite, Australia possesses climatic conditions that are entirely favourable for swimming and beach recreation, but a significant portion of the territory into the depth of the country is uninhabited and represents deserts that in no way fit the purposes of recreation. Such situation with Australia resembles that of Egypt. Besides, occupying the whole continent, the country has no land state borders and therefore has no mass tourist flows from the neighbours. Furthermore, major countries of origin of tourists are too far. Hence, Australia is not intensely visited due to the absence of land state border and remoteness from major regions of tourists' origin. And it is due to the 
same reasons that the income from inbound tourism per one arrival is among the largest in the world (US\$4,449.00).

Brazil is somehow similar to Australia, since it also has a long sea coast, a climate that is favourable for swimming and beach recreation, and a comparable territory. Though Brazil's land state border is long, it represents no factor of formation of tourist flows from neighbouring countries, since it runs through hard-to-access uninhabited territories, in particular, through the Amazon forests or high mountain ranges of the Andes. Taking into account availability of three more big countries from South America in this field, it is hard to escape a conclusion that mass international tourism flows have not yet formed on this continent. However, the most essential thing is that local geographical conditions favour domestic tourism, and people from these countries feel no great need in travels abroad. The fact is proved by the figure of total arrivals to all countries of South America in 2016 (33.9 million), which is a bit less than to Great Britain.

If median for the excerption receipts from inbound tourism per arrival are taken into account, the Field III countries should be divided into big countries of low-profitable and highly profitable extensive inbound tourism (see Table 7). Further analysis of these countries was similar to that provided for countries entered in Field II. Due to the complexity of calculations of weighted average distances to tourists' countries of origin, only few arising the greatest interest Field III countries were analysed (see Table 8).

Table 8. Big countries of extensive inbound tourism (2016)

\begin{tabular}{|c|l|c|c|c|}
\hline № Country & $\begin{array}{c}\text { Weighted average } \\
\text { distances, km }\end{array}$ & $\begin{array}{c}\text { Consumption } \\
\text { expenditures, US\$ per } \\
\text { capita }\end{array}$ & $\begin{array}{c}\text { Tourism Receipts, } \\
\text { US\$ per arrival }\end{array}$ \\
\hline \multicolumn{5}{|c|}{ highly profitable } \\
\hline 1 & India & 5,307 & 1,045 & 1,586 \\
\hline 2 & Australia & 5,988 & 30,762 & 4,449 \\
\hline 3 & Brazil & 537,000 & 6,763 & 1,010 \\
\hline 4 & Norway & 285,000 & 39,796 & 1,055 \\
\hline & \multicolumn{5}{|c|}{ low-profitable } \\
\hline 5 & Canada & 378,000 & 28,995 & 906,000 \\
\hline
\end{tabular}

Source: authors' own work based on OECD Tourism Trends and Policies and World Bank Open Data

Though Norway and Canada appeared to be on the opposite sides of the median for the excerption profitability, they showed the closest figures with respect to all parameters. Comparatively low tourism receipts per arrival shown by countries with high per capita consumption expenditures of local population is explained by small weighted average distance to tourists' countries of origin (see Table 8).

With respect to India, per arrival receipts from inbound tourism exceeded the per capita annual consumption expenditures of local population, and this paradox cannot be explained by a mere fact that tourists arrive from afar (see Table 8).

As was stated earlier the profitability of inbound tourism also can depend on tourists' potentials of spending power expressed by their average expenditures per departure (see Formula 5). Tourists who arrived to India spent considerably much money per 1 departure on the average (US 1,278.00) (see Table 9). 
Table 9. Weighted average tourists' expenditures per departure - tourists who visited India in 2016

\begin{tabular}{|c|l|c|c|}
\hline \multicolumn{1}{|c|}{ Country } & \multicolumn{2}{c|}{ Arrivals, $\%$} & $\begin{array}{c}\text { Tourism expenditures, US\$ } \\
\text { per departure }\end{array}$ \\
\hline \multicolumn{2}{|c|}{ № } & \multicolumn{2}{c|}{ India } \\
\hline 1 & Bangladesh & 15.7 & 896 \\
\hline 2 & USA & 14.7 & 1,211 \\
\hline 3 & Great Britain & 10.7 & 915 \\
\hline 4 & Canada & 3.6 & 124 \\
\hline 5 & Malaysia & 3.4 & 1,587 \\
\hline 6 & Sri Lanka & 3.4 & 1,278 \\
\hline
\end{tabular}

Source: authors' own work based on OECD Tourism Trends and Policies and World Bank Open Data

Even tourists from one of the poorest countries in the world - Bangladesh - were sufficiently rich to spend more per one departure than the average per capita consumption expenditures of its population (US 692.00 in 2016). However, if we remember that it is less than $1 \%$ of people there who can afford travels abroad, the situation becomes clearer, and its name is social stratification. Thus, outbound tourism in Bangladesh mirrored the inbound one of India by these parameters.

Finally, it should be accentuated that extensive inbound tourism in Field III countries is in the first place due to their bigness, in particular, of their big territories, and the countries themselves failed to appear in Field II mainly due to geographical factors or poverty. Thus, the climate of the Scandinavian Peninsula is characterised by the dominance of uncomfortable temperatures for human thermal-physiological sensations. Australia has problems with transport accessibility, since it is cut off from the rest of the world by water and located too far from major markets of international tourism. South America has none mass international tourism flows formed due to almost every country's availability of favourable conditions for domestic tourism, in particular, for swimming and beach recreation, whereas their borderline territories are often hardto-get places and, consequently, scarcely inhabited which prevents the flows from the neighbours.

Field IV is represented by countries where the gross number of inbound tourists and arrivals per $1 \mathrm{~km}$ of the territory's conventional radius are less than the median values for this excerption (see Table 10).

Table 10. Small countries of not-intensive inbound tourism (2016)

\begin{tabular}{|c|l|c|c|c|}
\hline № & \multicolumn{1}{|c|}{ Country } & Arrivals & $\begin{array}{c}\text { Arrivals per } \\
\text { territory radius }\end{array}$ & $\begin{array}{c}\text { Receipts (US\$) per } \\
\text { arrival }\end{array}$ \\
\hline 1 & New Zealand & $3,370,000$ & 11,524 & 2,897 \\
\hline 2 & Colombia & $3,317,000$ & 5,509 & 1,683 \\
\hline 3 & Finland & $2,789,000$ & 8,501 & 1,470 \\
\hline 4 & Oman & $2,335,000$ & 7,439 & 1,024 \\
\hline 5 & Sri Lanka & $2,051,000$ & 14,192 & 2,238 \\
\hline 6 & Panama & $1,921,000$ & 12,386 & 3,360 \\
\hline 7 & Iceland & $1,792,000$ & 9,891 & 1,345 \\
\hline
\end{tabular}




\begin{tabular}{|c|c|c|c|c|}
\hline 8 & Ecuador & $1,418,000$ & 4,720 & 1,023 \\
\hline 9 & Kenya & $1,268,000$ & 2,944 & 1,160 \\
\hline 10 & Tanzania & $1,233,000$ & 2,248 & 1,749 \\
\hline 11 & Ethiopia & 871,000 & 1,469 & 2,455 \\
\hline 12 & Sudan & 800,000 & 896 & 1,261 \\
\hline 13 & Fiji & 792,000 & 10,386 & 1,324 \\
\hline 14 & Trinidad and Tobago & 409,000 & 10,121 & 1,731 \\
\hline 15 & Mongolia & 404,000 & 573 & 938 \\
\hline 16 & Madagascar & 293,000 & 678 & 3,116 \\
\hline 17 & Moldova & 121,000 & 1,166 & 2,835 \\
\hline 18 & Dominica & 78,000 & 5,048 & 2,538 \\
\hline \multicolumn{4}{|c|}{ median tourism receipts per arriva } & 923 US\$ \\
\hline 19 & Uruguay & $3,037,000$ & 12,823 & 718 \\
\hline 20 & Lithuania & $2,296,000$ & 15,938 & 612 \\
\hline 21 & Algeria & $2,039,000$ & 2,342 & 121 \\
\hline 22 & Guatemala & $1,906,000$ & 10,238 & 813 \\
\hline 23 & Latvia & $1,793,000$ & 12,505 & 715 \\
\hline 24 & Botswana & $1,574,000$ & 3,601 & 368 \\
\hline 25 & Nicaragua & $1,504,000$ & 7,408 & 427 \\
\hline 26 & Namibia & $1,469,000$ & 2,866 & 257 \\
\hline 27 & Salvador & $1,434,000$ & 17,523 & 810 \\
\hline 28 & Paraguay & $1,308,000$ & 3,635 & 272 \\
\hline 29 & Armenia & $1,260,000$ & 12,937 & 784 \\
\hline 30 & Bolivia & 959,000 & 1,622 & 862 \\
\hline 31 & Malawi & 849,000 & 4,372 & 35 \\
\hline 32 & Honduras & 838,000 & 4,436 & 835 \\
\hline 33 & Nepal & 753,000 & 3,479 & 661 \\
\hline 34 & Venezuela & 601,000 & 1,113 & 908 \\
\hline 35 & North Macedonia & 510,000 & 5,680 & 555 \\
\hline 36 & Guyana & 235,000 & 898 & 443 \\
\hline 37 & Papua New Guinea & 179,000 & 466 & 9 \\
\hline 38 & Sierra Leone & 55,000 & 364 & 745 \\
\hline
\end{tabular}

Source: authors' own work based on World Bank Open Data

These countries did not appear in other categories due to small territory, uncomfortable geographical conditions for tourism, but, most frequently, due to poverty (predominantly, the countries of Africa and Latin America). Small number of arrivals, inclusive of those per $1 \mathrm{~km}$ of the territory's conventional radius, is conditioned not only by poverty in these countries themselves but also in the part of the world they are located in. Such "want" is two-fold. Firstly, as was established in a separate study, 
in countries where the territory density of consumption expenditures of local population is less than US $\$ / \mathrm{km}^{2} 190,000$ (measured in 1996 dollars), tourism infrastructure is not advanced. This, in its turn, negatively tells on the formation of inbound tourist flows to such destinations. Secondly, outbound tourism activity of population with per capita consumption expenditures less than US\$3,000.00 (measured in 1996 dollars) is very low, and such countries are not capable of generating a big number of outbound tourists (Korol, 2018). Hence, where "poverty" rules, no mass international tourism can exist since "there is no money to travel and no destinations in close vicinity to visit".

Low tourism attractiveness of Finland is conditioned by the Dfc type of climate typical for the whole Scandinavian Peninsula, while Lithuania and Latvia are characterised by the dominance of Dfb climate. Both are uncomfortable for human thermal-physiological sensations. Their insignificant area is not capable of providing for mass extensive inbound tourism as it is with Canada or Russia which belong to Field III countries. But Norway and Sweden which are commeasurable with Finland, appeared in the same category of extensive inbound tourism, while Estonia which is similar to the rest of the Baltic states, is appropriated to Field I countries. Hence, these cases require a more thorough analysis.

Let us tabulate all indices that may effect on inbound tourism of these countries. Since climatic conditions are nearly the same, their territories should be considered, as well as some other indices whose influence on inbound tourism was already stated above: territory density of consumption expenditures of local population (DCE); weighted average distance to top countries of tourists' origin that account for $50-60 \%$ of all arrivals (see Table 11).

Table 11. Selected indices that may affect inbound tourism (2016)

\begin{tabular}{|c|l|c|c|c|c|}
\hline Field & \multicolumn{1}{|c|}{ Country } & Arrivals & Territory, $\mathrm{km}^{2}$ & DCE,US\$/. $\mathrm{km}^{2}$ & $\begin{array}{c}\text { Average distance, } \\
\mathrm{km}\end{array}$ \\
\hline I & Estonia & $3,131,000$ & 45,230 & 272,275 & 46 \\
\hline III & Norway & $5,960,000$ & 386,000 & 437,539 & 285 \\
\hline IV & Finland & $2,789,000$ & 338,150 & 389,454 & 562 \\
\hline IV & Latvia & $1,793,000$ & 64,590 & 262,358 & 146 \\
\hline
\end{tabular}

Source: authors' own work based on OECD Tourism Trends and Policies and World Bank Open Data

The analysis shows that the countries have divided into two pairs: Estonia and Latvia; and Norway and Finland. Having the smaller territory and the same density of consumption expenditures as in Latvia, Estonia accepts twice more inbound tourists. Norway is still more similar to Finland if their territories and DCE values are compared, but the former enjoys twice the number of arrivals. The most probable reason is the geographic disposition as witnessed by weighted average distance to top countries of tourists' origin. The countries belonging to Field IV, that is Finland and Latvia, showed twice and thrice more distance in comparison to Norway and Estonia correspondingly (see Table 11). 


\section{CONCLUSIONS}

Gross tourist arrivals and their relative value calculated per $1 \mathrm{~km}$ of the country's territory conventional radius to their best demonstrate the volume and the intensity of inbound tourism. Their confrontment to respective median values allows for classification of countries of destination as shown in the scheme:

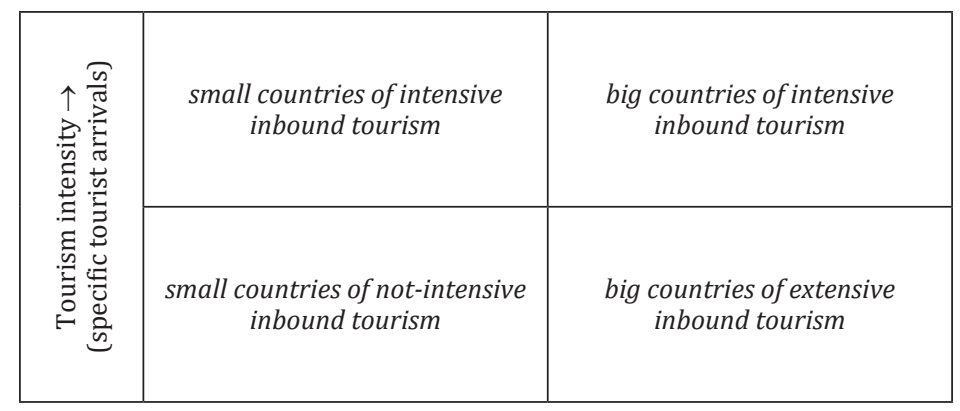

Tourism volume $\rightarrow$

(gross tourist arrivals)

Small countries of intensive inbound tourism are predominantly represented by tropical islands of the Caribbean Basin and Indian Ocean, as well as by the Mediterranean region. Higher tourism attractiveness of these destinations is mainly gained at the expense of natural conditions that favour swimming and beach recreation, namely, tropical and Mediterranean types of climate in combination with sea water areas, while small volume of inbound tourism is due to destinations' small territory.

Over half of big countries of intensive inbound tourism represent Europe. Such a situation is a matter of social-economic factor: a developed settlement and tourism infrastructure was formed there on the background of high specific household consumption expenditures of local population per $1 \mathrm{~km}^{2}$ of the territory. With this, the countries of the Scandinavian Peninsula were not included into this class, while countries of the Mediterranean were the most visited destinations. Hence, the effect of climate is obvious. The rest of European countries with no conditions that favour swimming and beach recreation predominantly possess moderate climate that provides for comfortable weather background for other kinds of tourism.

Small countries of intensive inbound tourism differed from big countries in the first place in the areas of their territories, which serve as a spatial basis for tourism. In particular, bigger territories provide for wider travel opportunities and higher landscape diversity. Also, the bigger the territory, the bigger the country's perimeter, and, therefore, the longer the state border, the bigger tourism flows from neighbours is received by the country.

Big countries of extensive inbound tourism show significant volume of inbound tourism in the first place due to their big territories. Among these, there were Scandinavian destinations of Europe, Canada and Russia, and Australia. Low tourism attractiveness of northern countries is explained by climatic conditions that are uncomfortable for human thermal-physiological sensations. Australia is washed by sea waters from all sides, and therefore has no tourism flows from the neighbours, as well as it is far distant from 
major countries of tourists' origin. Both situations can be described as unfavourable geographical disposition.

Small countries of not-intensive inbound tourism had considerably less volume and intensity of tourism arrivals due to their small territories, unfavourable geographical conditions, but what is most essential, due to population's poverty. Where poverty rules in this or that part of the world, mass international tourism cannot exist, since, due to low territory density of consumption expenditures, such countries of destination have no developed tourism infrastructure, while the poor per capita consumption expenditures in the countries of tourist's origin prevent from travels abroad.

\section{References}

Aleksandrova, A.Yu. (2002). Mezhdunarodnyi turizm [International tourism]. Moscow: AspectPress [in Russian].

Boniface, B., Cooper, C. (2009). Worldwide Destinations: The Geography of Travel and Tourism. Oxford: Butterworth Heinemann.

Charles R. Goeldner, J.R. Brent Ritchie (2009). Tourism: Principles, Practices, Philosophies. John Wiley \& Sons, Inc., Hoboken, New Jersey.

Horkavyi, V.K., Yarova, V.V. (2004). Matematychna statystyka [Mathematical Statistics]. Kyiv: VD Profesional [in Ukrainian].

Janczak, K., Patelak, K. (2013). Zagraniczna turystyka przyjazdowa do Polski w 2013 roku. [Inbound tourism to Poland in 2013]. Retrieved from http://docplayer.pl/4885847-Katarzynajanczak-krzysztof-patelak-zagraniczna-turystyka-przyjazdowa-do-polski-w-2013-roku. html [in Polish].

Korol, O., Skutar, T. (2008). Mizhnarodnyj turyzm: metodyka i materialy statystychnyx doslidzhen [International tourism: methods and materials of statistical research], Chernivtsi: Ruta [in Ukrainian].

Korol, O. (2018). Mizhnarodni turystychni potoky: suspilno-heohrafichni aspekty formuvannya ta heoprostorovyy rozpodil [International tourism flows: socio-geographical aspects of formation and geospatial distribution]. Chernivtsi: Yuriy Fedkovych Chernivtsi National University [in Ukrainian].

Liubitseva, 0.0. (2003). Rynok turystychnykh posluh [Market of tourist services]. Kyiv: Alterpress [in Ukrainian].

Mihai, D., Simoni, S. (2012). Analysing the Main Indicators of Global Tourism Flows in Evolution and Structure. Scientific Bulletin - Economic Sciences, University of Pitesti, vol. 11 (Special), pp 10-19.

OECD Tourism Trends and Policies 2018. Retrieved from https://www.oecd.org/cfe/tourism/

UNWTO Tourism Highlights (2001-2017). Retrieved from http:// www.unwto.org

Williams, S. (2009). Tourism geography: a new synthesis. New York: Routledge.

World Bank Open Data. Retrieved from https://data.worldbank.org

Oleksandr Korol, PhD, Yuriy Fedkovych Chernivtsi National University (Chernivtsi, Ukraine), Department of Geography and Management of Tourism. PhD in Geography, associate professor, Head of the Department of Geography and Management of Tourism, Yuriy Fedkovych Chernivtsi National University (Chernivtsi, Ukraine). He has graduated from the Yuriy Fedkovych Chernivtsi National University. Author's research interests concern issues of international tourism flows, tourism marketing, guided tour service.

ORCID: 0000-0002-1114-1090

\section{Address:}

Yuriy Fedkovych Chernivtsi National University

2 Kotsyubynskyi Str., 58012 Chernivtsi, Ukraine

e-mail: o.korol@chnu.edu.ua 
Volodymyr Krul, PhD, Yuriy Fedkovych Chernivtsi National University (Chernivtsi, Ukraine), Department of Physical Geography, Geomorphology and Paleogeography. PhD in Geography, professor, Head of the Department of Physical Geography, Geomorphology and Paleogeography, Yuriy Fedkovych Chernivtsi National University (Chernivtsi, Ukraine). Author's research interests concern issues of retrospective geography and ethno-demography. Academic interests also revolve around the research of geography of tourism, particularly in Ukraine.

ORCID: 0000-0003-1100-4149

\section{Address:}

Yuriy Fedkovych Chernivtsi National University

2 Kotsyubynskyi Str., 58012 Chernivtsi, Ukraine

e-mail: kroolv@ukr.net 